Herzschr Elektrophys 2015 · 26:148-154

DOI 10.1007/s00399-015-0360-z

Received: 28 January 2015

Accepted: 29 January 2015

Published online: 8 March 2015

(c) The Author(s) 2015. This article is published

with open access at Springerlink.com

Andreas Goette $^{1}$ - G. Benninger ${ }^{2}$ D. Pittrow ${ }^{3}$. W.D. Paar ${ }^{4}$ B. von Stritzky ${ }^{4}$

R.F. Bosch ${ }^{5}$

${ }^{1}$ Department of Cardiology and Intensive Care Medicine, Medizinische Klinik II,

St. Vincenz-Hospital Paderborn GmbH, Paderborn, Germany

${ }^{2}$ Atrial Fibrillation Competence Network (AFNET) Association, Münster, Germany

${ }^{3}$ Institute for Clinical Pharmacology, Medical Faculty, Technical University Carl Gustav Carus,

Dresden, Germany

${ }^{4}$ Medical Department, Sanofi-Aventis Deutschland GmbH, Berlin, Germany

${ }^{5}$ Cardio Centrum Ludwigsburg-Bietigheim, Ludwigsburg, Germany

\title{
One-year safety and quality of life outcomes in patients with atrial fibrillation on dronedarone: prospective, non-interventional study in German ambulatory care
}

agent compared with amiodarone was reduced and its plasma half-life substantially shortened thought to reduce organ toxicity due to cumulative effects.

The drug has been launched in 2010 in Germany under the brand name Multaq $^{\circledR}$. Based on the results of new trials and pharmacovigilance reports its labelling has been amended several times. According to the current summary of product characteristics, Multaq ${ }^{\circledR}$ is indicated for the maintenance of sinus rhythm after successful cardioversion in adult clinically stable patients with paroxysmal or persistent AF [14]. Due to its safety profile, the agent should only be prescribed after alternative treatment options have been considered. Multaq ${ }^{\circledR}$ should not be given to patients with left ventricular systolic dysfunction or to patients with current or previous episodes of heart failure [14]. Careful monitoring during dronedarone administration is recommended with regular assessment of cardiac, hepatic and pulmonary function.

While dronedarone has been extensively documented in the context of clinical studies [15], there is a paucity of data on the use under real life conditions, with the exception of a retrospective database analysis of all patients treated with the drug between 2010 and 2012 in Sweden [16]. The real life patient population often differs from patient cohorts in controlled clinical studies with regards to demographic characteristics, comorbidities and concomitant diseases. Data collected in non-interventional studies like IMPULS can complement the findings of pivotal studies. We aimed to collect such data, with particular focus on QoL.

\section{Methods}

Study design and timelines. IMPULS was a prospective multicentre non-interventional study (NIS) according to $\$ 67$ (6) German Drug Law (AMG) to document the management/treatment of consecutive patients treated with Multaq ${ }^{\circledR}$ over a period of 12 months. All procedures followed were in accordance with the ethical standards with the Helsinki Declaration of 1975 (in its most recently amended version). The study materials were reviewed and approved by the ethics committees of the Ärztekammer Westfalen-Lippe and of the Medical Faculty of Wilhelms University of Münster. Informed consent was obtained from all patients included in the study. The study was performed between January 2012 

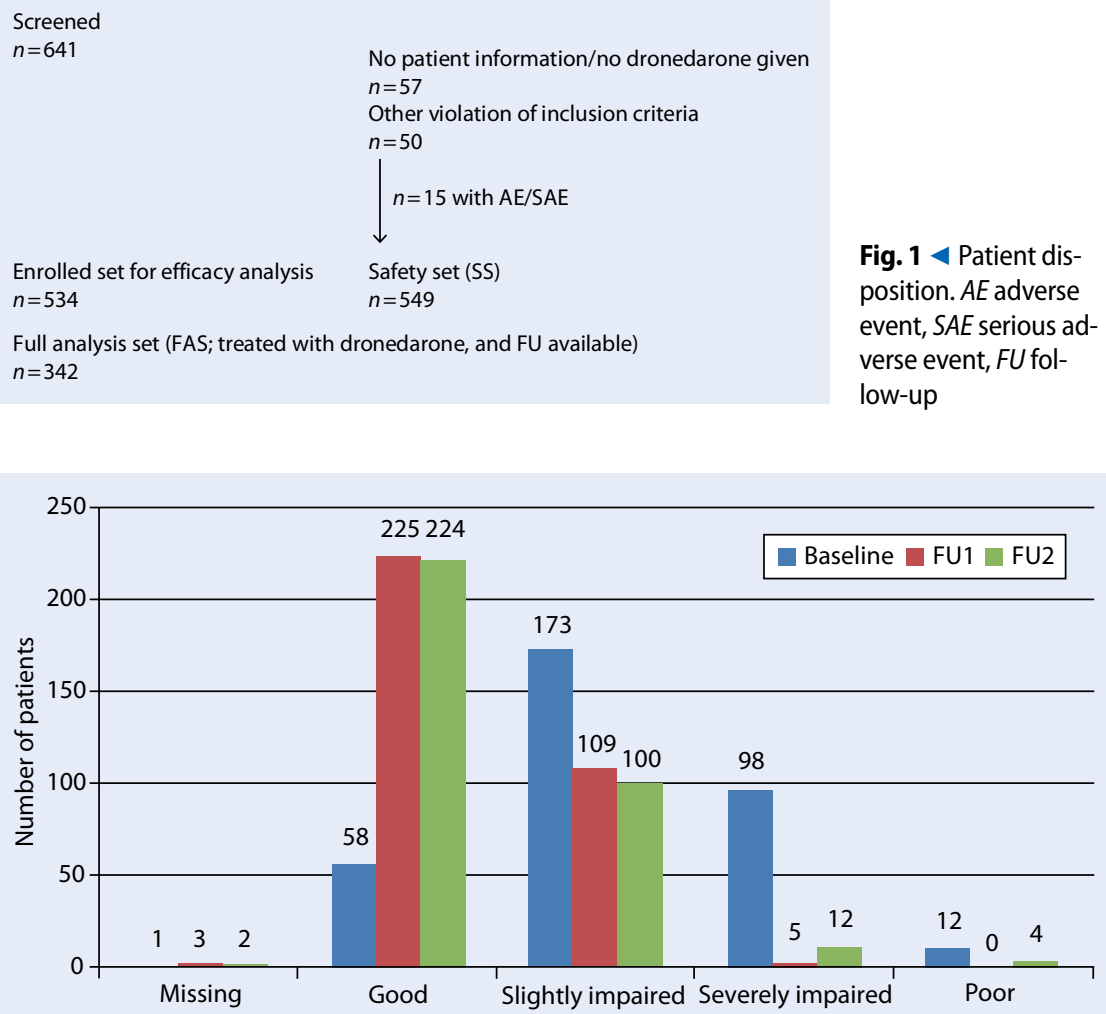

Fig. $2 \Delta$ Self-reported health state of patients at baseline, at follow-up 1 ( 6 months) and follow-up 2 (12 months) (first patient in) and December 2013 (last patient out).

Centres. Office-based cardiologists, general practitioners and internists were eligible for participation. Selection of centres aimed to obtain a representative distribution with respect to geography and physician specialisation, respectively.

Patients. Patients were eligible for documentation, if they (1) were newly treated with dronedarone or were on maintenance treatment with dronedarone no longer than 3 months; (2) had paroxysmal or persistent $\mathrm{AF}$ and at least one cardiovascular risk factor (arterial hypertension, diabetes mellitus, previous stroke, transient ischaemic attack, arterial embolism, left atrial diameter $\geq 50 \mathrm{~mm}$ ); (3) had provided written informed consent to participate in the study. No explicit exclusion criteria were applied to avoid selection bias. All diagnoses were provided by the treating physician and were not adjudicated by third parties.
Fig. $1<$ Patient disposition. $A E$ adverse event, $S A E$ serious adverse event, FU follow-up (recording of last alanine aminotransferase (ALT) values, renal function (creatinine value)), and in the case of vitamin $\mathrm{K}$ treatment, the international normalised ratio.

With regards to AF, the following information was documented: month of first diagnosis, type, current rhythm according to last ECG and symptoms. Further, therapy within the last 12 months, hospitalisations due to AF or other reasons, current therapy for the prevention of thromboembolic complications, management of AF in the last 12 months were documented. At 3 months, ALT and creatinine values between the initiation of dronedarone therapy and the visit were noted.

At the two FU visits at 6 months and 12 months, physicians predominantly documented current symptoms, therapy for AF and anticoagulation, newly occurring vascular events (transient ischaemic attacks, stroke, myocardial infarction, heart failure or other cardiac events) and detailed information on cardioversion or other therapy. Medication for rhythm control of AF was recorded by VaughanWilliams classification.

Data entry and analysis. Data were collected using paper-pencil case record forms. Duplicate data entry was performed by the contract research organisation, and plausibility checks were executed using a validation plan.

The safety set consisted of 549 patients, the enrolled set of 534 patients and the full analysis set of all patients treated at least once with dronedarone and FU data available for 342 patients (• Fig. 1).

\section{Statistical analysis} physician's office. As generic instruments, the 100-point EQ-5D visual analogue scale (VAS) [17] and the short form 12 (SF-12) [18] were applied. Further, the AF-QoL questionnaire as disease-specific questionnaire was administered $[19,20]$.

Parameters. At baseline, characteristics on demographics (gender, age and employment status), basic data and vital signs, cardiac risk factors, cardiac history and concomitant diseases were noted. Particular focus was on hepatic function
Continuous variables are reported as mean with standard deviation, categorical variables as percentage of patient population. Due to incomplete answers and multiple answering options, observed numbers and percentages do not always add up to exactly $100 \%$. Comparisons between baseline and FU were performed with the two-tailed Student's paired sample $t$-test. Data were analysed using the SAS statistical package Version 9.2. 
Herzschr Elektrophys 2015 - 26:148-154 DOI 10.1007/s00399-015-0360-z

(c) The Author(s) 2015. This article is published with open access at Springerlink.com

A. Goette - G. Benninger - D. Pittrow - W.D. Paar · B. von Stritzky · R.F. Bosch

One-year safety and quality of life outcomes in patients with atrial fibrillation on dronedarone: prospective, non-interventional study in German ambulatory care

Abstract

Background and aims. The multichannel blocker dronedarone is currently indicated for the maintenance of sinus rhythm after successful cardioversion in adult clinically stable patients with paroxysmal or persistent atrial fibrillation (AF), with careful monitoring of cardiac, hepatic and renal function. We aimed to investigate patients' quality of life (QoL) and tolerability and effectiveness of dronedarone under real life conditions. Methods. In the 1-year prospective, non-interventional IMPULS study, 161 office-based cardiologists, general practitioners and internists throughout Germany documented 549 patients with AF who were currently or newly prescribed dronedarone (safety set, SS). Of those, 342 patients (full analysis set, FAS) provided data on QoL at baseline, 6 months and 12 months).

Results. Mean age of patients was $67.6 / 66.3$ years; $53.0 \% / 57.3 \%$ were men (SS/FAS). AF type at inclusion in the SS/FAS was paroxysmal in $71.9 \% / 71.3 \%$ and persistent in $26.0 \% / 26.6 \%$ (missing in $2.0 \% / 2.0 \%$ ). The proportion of patients in sinus rhythm increased from $44.6 \%$ at baseline to $70.2 \%$ (SS). The mean value on the 100 -point visual analogue scale (EuroQol EQ-5D) increased from $62.3 \pm 17.1$ at baseline by $11.4 \pm 18.7$ points (FAS, $p<0.0001$ ). The AF-QoL Psychological Domain improved from $44.6 \pm 22.6$ at baseline by $16.0 \pm 23.5$ points at 1 year $(p<0.0001)$, the AF-QoL physical domain from $49.5 \pm 22.1$ by $10.9 \pm 22.5$ points $(p<0.0001)$, and the AF-QoL sexual domain from $61.8 \pm 27.1$ by $6.6 \pm 28.2$ points $(p<0.0001)$. In all, 136 patients ( $24.8 \%$ of all patients in the safety set) had at least one adverse drug reaction (ADR) causally related to dronedarone. Conclusions. Various dimensions of quality of life of patients with AF were improved on dronedarone under clinical practice conditions. No previously unknown safety issues were noted.

Keywords

Atrial fibrillation - Treatment - Observational . Quality of life - Long term · Safety · Outcomes

\section{Sicherheit und Lebensqualität bei Patienten mit Vorhofflimmern unter Therapie mit Dronedaron: prospektive, nicht-interventionelle Studie über 1 Jahr in der ambulanten Versorgung in Deutschland}

\section{Zusammenfassung}

Hintergrund und Ziele. Der Mehrkanalblocker Dronedaron ist - nachdem alternative Behandlungsoptionen in Erwägung gezogen wurden - angezeigt zum Erhalt des $\mathrm{Si}$ nusrhythmus nach einer erfolgreichen Kardioversion bei erwachsenen, klinisch stabilen Patienten mit paroxysmalem oder persistierendem Vorhofflimmern (VHF). Die kardiale, hepatische und renale Funktion sind zu kontrollieren. Wir untersuchten die Lebensqualität der Patienten unter Dronedaron sowie die Verträglichkeit und Wirksamkeit der des Antiarrhythmikums unter Praxisbedingungen. Methoden. In der prospektiven, nicht-interventionellen IMPULS-Studie dokumentierten 161 niedergelassene Kardiologen, hausärztlich tätige Internisten und Allgemeinärzte in Deutschland 549 Patienten mit VHF (Safety Set (SS)), die bereits Dronedaron erhielten oder denen die Substanz erstmalig verschrieben wurde. Davon hatten 342 Patien- ten (Full-Analysis Set, FAS) Daten zur Lebensqualität zu Beginn der Studie sowie nach 6 und 12 Monaten.

Das mittlere Alter der Patienten lag bei 67,6/66,3 Jahren und 53,0\%/57,3\% waren Männer (SS/FAS). Hinsichtlich des VHF-Typs wurde die paroxysmale Manifestation bei $71,9 \% / 71,3 \%$ und die persistierende bei 26,0\%/26,6\% angegeben (fehlende Angabe bei $2,0 \% / 2,0 \%$;) (SS/FAS). Der Anteil der Patienten im Sinusrhythmus nahm von $44,6 \%$ bei Dokumentationsbeginn auf $70,2 \%$ nach 1 Jahr zu (SS). Die Lebensqualität verbesserte sich auf der 100-stufigen visuellen Analogskala (EuroQol EQ-5D) von 62,3 $\pm 17,1$ Punkten um 11,4 $\pm 18,7$ Punkte (FAS; $p<0,0001$ ). Hinsichtlich der Dimension „psychische Beeinträchtigung" im AF-QoL (Ausgangsmittelwert \pm SD 44,6 $\pm 22,6$ ) wurde eine Verbesserung von 16,0 $\pm 23,5$ Punkten nach $1 \mathrm{Jahr}$ dokumentiert. Bei „,körperliche Beeinträch- tigung" (von 49,5 $\pm 22,2$ ) betrug die Verbesserung 10,9 $\pm 22,5$ Punkte $(p<0.0001)$, und bei , Sexualität" (von 61,8 $\pm 27,1$ Punkten) $6,6 \pm 28,2$ Punkte $(p<0.0001)$. Nebenwirkungen, die vom dokumentierenden Arzt als möglicherweise oder sicher in Beziehung zu Dronedaron stehend eingestuft wurden (unerwünschte Arzneimittelwirkungen, UAW), traten bei 136 Patienten auf (24,8\% des SS). Schlussfolgerung. Unter Alltagsbedingungen verbesserten sich verschiedene Dimensionen der Lebensqualität während der Therapie mit Dronedaron. Das Medikament wurde gut vertragen.

\section{Schlüsselwörter}

Vorhofflimmern · Therapie .

Beobachtungsstudie · Sicherheit .

Lebensqualität · Langzeitergebnisse

\section{Results}

A total of 161 office-based cardiologists, general practitioners and internists throughout Germany took part in this study.

Patient characteristics. Characteristics of patients are displayed in $\bullet$ Table 1.
Mean age of patients was 66.3 years, $57.3 \%$ were men. Patients had paroxysmal AF in $71.4 \%$ and persistent $\mathrm{AF}$ in $26.6 \%$ (missing 2.1\%). Comorbidities were frequent, in particular arterial hypertension, coronary artery disease and diabetes mellitus.

\section{Primary effectiveness variables (FAS)}

AF-QoL. The AF-QoL psychological domain improved from $44.6 \pm 22.6$ at baseline to $56.7 \pm 21.7$ at FU1 (i.e. $+12.1 \pm 20.8$ points, $p<0.0001)$, and to $60.6 \pm 22.6$ at FU2 $(+16.0 \pm 23.5$ points, $p<0.0001)$. Further, the AF-QoL physical domain im- 


\begin{tabular}{|lll}
\hline \multicolumn{3}{l}{ Table 1 Demographic variables AF type and comorbidies inclusion (FAS, $n=342)$} \\
\hline Variable & $\boldsymbol{n}$ & Value \\
\hline Age, years (mean) & 342 & $66.3 \pm 9.7$ \\
\hline$<65$ years (\%) & 134 & 39.2 \\
\hline$\geq 65$ years (\%) & 208 & 60.8 \\
\hline Gender, male (\%) & 196 & 57.3 \\
\hline Female (\%) & 146 & 42.7 \\
\hline Body mass index, kg/m ${ }^{2}$ mean \pm SD) & 341 & $28.4 \pm 4.3$ \\
\hline AF type (\%) & & \\
\hline Paroxysmal & 244 & 71.4 \\
\hline Persistent & 91 & 26.6 \\
\hline Missing & 7 & 2.1 \\
\hline AF duration, days (median) & 334 & 396 \\
\hline Comorbidities (\%) & & \\
\hline Arterial hypertension & 321 & 93.9 \\
\hline Diabetes mellitus & 80 & 23.4 \\
\hline Hyperthyreosis & 13 & 3.8 \\
\hline Pathological alcohol consumption & 4 & 1.2 \\
\hline Stroke/TIA & 24 & 7.0 \\
\hline Left atrial diameter $\geq 50$ mm & 47 & 13.7 \\
\hline Valvular defect & 60 & 17.5 \\
\hline Coronary artery disease & 74 & 21.6 \\
\hline
\end{tabular}

Table 2 Overview on adverse drug reactions (ADR)

\begin{tabular}{|llll|}
\hline Category & Events $(\boldsymbol{n})$ & Patients $(\boldsymbol{n})$ & \% of patients at risk \\
\hline Any ADR related & 281 & 136 & 24.8 \\
\hline Non-serious ADR & 116 & 57 & 10.4 \\
\hline Serious ADR & 165 & 92 & 16.8 \\
\hline
\end{tabular}

proved from $49.5 \pm 22.2$ at baseline to $59.8 \pm 20.5$ at FU1 (i.e. $+10.3 \pm 19.5$ points, $p<0.0001)$, and to $60.3 \pm 24.0$ at FU2 $(+10.9 \pm 22.5$ points, $p<0.0001)$. Finally, the AF-QoL sexual domain improved from $61.8 \pm 27.1$ at baseline to $68.3 \pm 24.8$ at FU1 (i.e. $+6.5 \pm 24.2, p<0.0001$ ), and to $68.4 \pm 26.7$ at FU2 $(+6.6 \pm 28.2$ points, $p<0.0001)$.

EQ-5D. The mean value on the 100 -point VAS increased from $62.3 \pm 17.1$ at baseline to $73.1 \pm 17.0$ at FU1 $(+10.8 \pm 17.9$ points, $p<0.0001)$ and to $73.9 \pm 17.3$ at FU2 $(+11.4 \pm 18.7$ points, $p<0.0001)$.

For both the AF-QoL and the EQ-5D, there were no important differences between men and women or in patients with paroxysmal versus persistent AF.

\section{Secondary effectiveness variables}

SF-12. The mean SF-12 physical summary scale increased from $42.3 \pm 8.6$ points at baseline to $46.2 \pm 7.9$ at FU1 $(+4.0 \pm 8.6$ points, $p<0.0001)$ and to $46.5 \pm 9.0$ $(+4.3 \pm 9.3$ points, $p<0.0001)$ at FU2. The mental summary scale increased from $43.4 \pm 11.9$ points at baseline to $47.9 \pm 10.0$ at FU1 $(+4.4 \pm 10.3$ points, $p<0.0001)$ and to $48.1 \pm 9.8(+4.8 \pm 11.3$ points, $p<0.0001)$ at FU2.

Rhythm control rates. The proportion of patients in sinus rhythm increased from $44.6 \%$ at baseline to $70.2 \%$ at FU1 and $70.9 \%$ at FU2.

General health evaluation. While at baseline, the great majority of patients reported at least slight or moderate impairment of their general health, at FU their self-reported state had considerably improved (• Fig. 2).

\section{Safety and tolerability (safety set)}

Overall assessment. A total of 281 individual adverse drug reactions causally related to Multaq ${ }^{\circledR}$, of which 165 were rat- ed as serious and 116 as non-serious, were reported in 136 patients ( $24.6 \%$ of all patients in the safety set, - Table 2). Most serious ADRs (SADR) occurred in the category 'cardiac disorders' (94 SADRs), followed by 'general disorders and administration site conditions' (23 SADRs), 'investigations' (18 SADRs) and 'respiratory, thoracic and mediastinal disorders' (11 SADRs).

AF was the most frequently noted SADR (in $13.8 \%$ of patients). All other events occurred in less than $2 \%$ (e.g. drug ineffectiveness in $1.5 \%$, heart failure in $1.3 \%$ and dyspnoea in $1.3 \%$ ). The most frequent non-serious ADRs were increased ALT ( $2.0 \%$ of patients), nausea $(1.3 \%)$ and diarrhoea $(1.3 \%)$; all other events were noted less than $1 \%$.

Out of the 136 patients with SADR or ADR, a total of 110 discontinued Mul$\operatorname{taq}^{\circledR}$ therapy. The most frequently noted underlying conditions ( $\bullet$ Table 3 ) were AF (10.4\% of patients), increased ALT ( $2.2 \%$ of patients), dyspnoea ( $2.2 \%$ of patients) and drug ineffectiveness (1.6\% of patients).

Laboratory values. ALT values were increased at least 3 times above the upper reference limit in 60 patients $(10.9 \%)$. There was no specific time pattern in the occurrence of the elevations.

Elevations of creatinine at least 2 times above the upper reference limit were not documented in this study.

\section{Discussion}

To the best of our knowledge, the IMPULS study is the only prospective observational study that specifically documents the use of dronedarone under clinical practice conditions. Previous similar AF studies in Germany such as MOVE [21] or ATRIUM [22] were performed too early to accrue significant patient numbers.

IMPULS used similar inclusion criteria as the ATHENA study and focused on patients with AF who had additional risk factors for death [23]. In that study, patients in the dronedarone group had higher rates of bradycardia, QT-interval prolongation, nausea, diarrhoea, rash and an increased serum creatinine level than the placebo group, whereas rates of thyroid- 


\section{Original Contribution}

Table 3 ADR leading to withdrawal of Multaq ${ }^{\circledR}$ (safety set)

\begin{tabular}{|c|c|c|c|}
\hline System Organ Class & Term & Frequency & $\%$ of patients \\
\hline \multirow[t]{8}{*}{ Cardiac disorders } & & 80 & \\
\hline & Arrhythmia & 2 & 0.36 \\
\hline & Atrial fibrillation & 60 & 10.38 \\
\hline & Bradycardia & 2 & 0.36 \\
\hline & Cardiac failure & 7 & 1.28 \\
\hline & Left ventricular dysfunction & 2 & 0.36 \\
\hline & Palpitations & 3 & 0.55 \\
\hline & Tachyarrhythmia & 2 & 0.36 \\
\hline \multirow{10}{*}{$\begin{array}{l}\text { General disorders and ad- } \\
\text { ministration site conditions }\end{array}$} & & 39 & \\
\hline & Condition aggravated & 2 & 0.36 \\
\hline & Drug ineffective & 10 & 1.64 \\
\hline & Drug intolerance & 4 & 0.73 \\
\hline & Fatigue & 2 & 0.36 \\
\hline & General physical health deterioration & 2 & 0.36 \\
\hline & Ill-defined disorder & 4 & 0.73 \\
\hline & Local swelling & 2 & 0.36 \\
\hline & Malaise & 3 & 0.55 \\
\hline & Oedema peripheral & 2 & 0.36 \\
\hline \multirow[t]{9}{*}{ Investigations } & & 37 & \\
\hline & Alanine aminotransferase $\uparrow$ & 12 & 2.19 \\
\hline & Aspartate aminotransferase $\uparrow$ & 2 & 0.36 \\
\hline & Blood creatinine $\uparrow$ & 3 & 0.55 \\
\hline & Gamma-glutamyltransferase $\uparrow$ & 2 & 0.36 \\
\hline & Hepatic enzyme $\uparrow$ & 4 & 0.73 \\
\hline & International normalised ratio $\uparrow$ & 2 & 0.36 \\
\hline & Liver function test abnormal & 3 & 0.55 \\
\hline & Transaminases $\uparrow$ & 4 & 0.73 \\
\hline \multirow[t]{6}{*}{ Gastrointestinal disorders } & & 27 & \\
\hline & Abdominal discomfort & 5 & 0.91 \\
\hline & Abdominal pain upper & 2 & 0.36 \\
\hline & Diarrhoea & 7 & 1.28 \\
\hline & Gastrointestinal disorder & 2 & 0.36 \\
\hline & Nausea & 7 & 1.28 \\
\hline \multirow{4}{*}{$\begin{array}{l}\text { Respiratory, thoracic and } \\
\text { mediastinal disorders }\end{array}$} & & 17 & \\
\hline & Dyspnoea & 12 & 2.19 \\
\hline & Dyspnoea exertional & 2 & 0.36 \\
\hline & Interstitial lung disease & 2 & 0.36 \\
\hline \multirow[t]{4}{*}{ Nervous system disorders } & & 11 & \\
\hline & Dizziness & 4 & 0.73 \\
\hline & Headache & 2 & 0.36 \\
\hline & Syncope & 3 & 0.55 \\
\hline \multicolumn{2}{|c|}{ Skin and subcutaneous tissue disorders } & 11 & \\
\hline & Hyperhidrosis & 2 & 0.36 \\
\hline & Rash & 3 & 0.55 \\
\hline
\end{tabular}

Table shows reactions that occurred in more than 1 patient. $\uparrow$, increased

and pulmonary-related adverse events were not significantly different between the two groups. Dronedarone reduced the incidence of hospitalisation due to cardiovascular events or death [23].

In our study, dronedarone was welltolerated, and the reported adverse drug reactions were in line with current knowledge. The most frequently reported reason for drug withdrawal was recurrence of AF and therefore not related to safety per se. With respect to laboratory values, the rate of abnormal liver function tests was substantially higher in IMPULS (10.9\%) compared with ATHENA (0.5\%) which might be due to the fact that in the latter trial there were no scheduled hepatic tests. Conversely, in ATHENA an increase in serum creatinine was noted in $4.7 \%$, compared with $0 \%$ in our study. A recent retrospective database analysis on all 4856 patients treated with dronedarone in Sweden during 2010-2012, i.e., before the implementation of restrictions in the labelling of the drug, showed that patients selected for treatment were lowrisk and had lower mortality than expected from the general population, or than AF patients on other antiarrhythmic medication [16]. Further, the risk of incident liver disease was significantly lower among dronedarone patients than among other AF patients (HR 0.57; $95 \%$ CI $0.34-$ 0.92) [16].

It is important to represent the patient perspective in the management of $\mathrm{AF}$ [24]. Thus, the number of studies that reported QoL in AF has steadily increased in the last years. The instrument 'typically used' is the SF-36, but the SF-12 has also been shown to provide robust results in the Birmingham Atrial Fibrillation Treatment of the Aged study [25]. In IMPULS, two questionnaires were administered in a complimentary manner to assess QoL, namely the SF-12 and EQ-5D VAS as generic and the AF-QoL as disease-specific instrument $[15,16]$. Generic instruments document general aspects of physical, mental or social functionality, which can similarly be compromised in diverse diseases, and can be compared across these diseases using the instruments. However, they are often less sensitive $[19,20]$ as health improvement and QoL instruments are often not represented by a generic tool sufficiently [26]. Disease-specific questionnaires such as the AF-QoL focus on typical aspects of the disease, which may be experienced subjectively very differently by patients.

As it has been performed in a similar setting (office-based physicians in Ger- 
many), the MOVE cross-sectional study is particularly useful to compare results [27]. On the 100-point VAS, the 3354 patients overall had a value of $68 \pm 18$ points (paroxysmal 70, persistent 68, permanent 66 points) and thus a lower value compared with IMPULS (66 at baseline, 74 at FU). As in MOVE, [27] QoL scores were slightly worse in women compared to men, for all types of AF. It was notable that during the FU of the study in IMPULS, QoL on all instruments was substantially improved with the greatest effect already at the first FU visit. The observed improvement of 11 points on the VAS corresponds to a clinical improvement of about one category in the European Heart Rhythm Association (EHRA) score (which is reported in four classes) and thus represents a significant effect [28]. This finding may be due to the clinical effect of dronedarone, but could also be an unspecific consequence of intensive care of patients in the context of this study.

Limitations. A number of limitations need to be addressed when the current results are interpreted. Given IMPULS was an open-label non-randomised study, different biases can obscure any true causal association [29]. As participating centres may have more scientific interest in particular in QoL investigations, results may not reflect outcomes in less well-organized institutions. Clinical decisions of the treating physicians may assign selected patients to drug treatment guided by disease severity, presence of comorbidities and other factors. This can potentially introduce allocation or channelling bias and confound the association between treatment and outcomes. The sample size was relatively small, and therefore the study was not powered to detect previously unknown, rare side effects of dronedarone. FU periods longer than 1 year are desirable to assess the long-term effects of the drug.

In conclusion, in this contemporary study on the use of dronedarone under clinical practice various dimensions of QoL of patients with AF were improved in the long term. No previously unknown safety issues were identified.

\section{Corresponding address}

\section{Prof. Dr. A. Goette}

Department of Cardiology and Intensive Care

Medicine, Medizinische Klinik II

St. Vincenz-Hospital Paderborn GmbH

Am Busdorf 2, 33098 Paderborn

andreas.goette@vincenz.de

\section{Compliance with ethical guidelines}

Conflicts of interest. A. Goette has received honoraria for scientific talks on behalf of Aventis, Bayer Health Care, BMS/Pfizer, Daiichi-Sankyo, and Boehringer Ingelheim. R.F. Bosch has received honoraria for scientific talks on behalf of Sanofi, Bayer, Boehringer Ingelheim and Pfizer, and consultancy fees from Boehringer Ingelheim and Pfizer. D. Pittrow has received consultancy fees from Actelion, Aspen, Bayer Health Care, Boehringer Ingelheim, SanofiAventis, Novartis, Daiichi Sankyo, and Pfizer. W.D. Paar and B. von Stritzky are full-time employees of Sanofi-Aventis GmbH. G. Benninger states there is no conflict of interest.

Open Access This article is distributed under the terms of the Creative Commons Attribution License which permits any use, distribution, and reproduction in any medium, provided the original author(s) and the source are credited.

\section{References}

1. Go AS, Hylek EM, Phillips KA, Chang Y, Henault LE, Selby JV et al (2001) Prevalence of diagnosed atrial fibrillation in adults: national implications for rhythm management and stroke prevention: the AnTicoagulation and Risk Factors In Atrial Fibrillation (ATRIA) Study. JAMA 285(18):2370-2375

2. Camm AJ, Kirchhof P, Lip GY, Schotten U, Savelieva I, Ernst S et al (2010) Guidelines for the management of atrial fibrillation: The Task Force for the Management of Atrial Fibrillation of the European Society of Cardiology (ESC). Eur Heart J 31(19):2369-2429

3. Valderrama AL, Dunbar SB, Mensah GA (2005) Atrial fibrillation: public health implications. Am J Prev Med 29(5 Suppl 1):75-80

4. Vidaillet H, Granada JF, Chyou PH, Maassen K, Ortiz M, Pulido JN et al (2002) A population-based study of mortality among patients with atrial fibrillation or flutter. Am J Med 113(5):365-370

5. Wang TJ, Larson MG, Levy D, Vasan RS, Leip EP, Wolf PA et al (2003) Temporal relations of atrial fibrillation and congestive heart failure and their joint influence on mortality: the Framingham Heart Study. Circulation 107(23):2920-2925

6. Singh SN, Tang XC, Singh BN, Dorian P, Reda DJ, Harris CL et al (2006) Quality of life and exercise performance in patients in sinus rhythm versus persistent atrial fibrillation: a Veterans Affairs Cooperative Studies Program Substudy. J Am Coll Cardiol 48(4):721-730

7. Dorian P, Jung W, Newman D, Paquette M, Wood $\mathrm{K}$, Ayers GM et al (2000) The impairment of healthrelated quality of life in patients with intermittent atrial fibrillation: implications for the assessment of investigational therapy. J Am Coll Cardiol 36(4):1303-1309
8. Howes CJ, Reid MC, Brandt C, Ruo B, Yerkey MW, Prasad B et al (2001) Exercise tolerance and quality of life in elderly patients with chronic atrial fibrillation. J Cardiovasc Pharmacol Ther 6(1):23-29

9. Kang Y, Bahler R (2004) Health-related quality of life in patients newly diagnosed with atrial fibrillation. Eur J Cardiovasc Nurs 3(1):71-76

10. Paquette M, Roy D, Talajic M, Newman D, Couturier A, Yang C et al (2000) Role of gender and personality on quality-of-life impairment in intermittent atrial fibrillation. Am J Cardiol 86(7):764-768

11. van den Berg MP, Hassink RJ, Tuinenburg AE, van Sonderen EF, Lefrandt JD, de Kam PJ et al (2001) Quality of life in patients with paroxysmal atrial fibrillation and its predictors: importance of the autonomic nervous system. Eur Heart J 22(3):247253

12. Kirch W, Pittrow D, Bosch RF, Kohlhaussen A, Willich SN, Rosin L et al (2010) Health-related quality of life of patients with atrial fibrillation managed by cardiologists: MOVE study. Dtsch Med Wochenschr 135(Suppl 2):S26-S32

13. Zareba KM (2006) Dronedarone: a new antiarrhythmic agent. Drugs Today (Barc) 42(2):75-86

14. European Medicines Agency (EMA), MULTAQ $400 \mathrm{mg}$ film-coated tablets (manufacturer: Sanofi Aventis). Summary of product characteristics. Last update 26 June 2014. http://www.ema.europa.eu/ema/index.jsp?curl=pages/medicines/human/medicines/001043/human_med_001207. jsp\&mid=WC0b01ac058001d124. Accessed 11 Sept 2014

15. Schmitt J, Lewalter T, Pittrow D, Duray G, Goette A, Brachmann J et al (2010) Clinical profile of the new antiarrhythmic drug dronedarone. Dtsch Med Wochenschr 135(Suppl 2):S38-S42

16. Friberg $L$ (2014) Safety of dronedarone in routine clinical care. J Am Coll Cardiol 63(22):2376-2384

17. Greiner W, Claes C, Busschbach JJ, von der Schulenburg JM (2005) Validating the EQ-5D with time trade off for the German population. Eur J Health Econ 6(2):124-130

18. Ware J Jr, Kosinski M, Keller SD (1996) A 12-Item Short-Form Health Survey: construction of scales and preliminary tests of reliability and validity. Med Care 34(3):220-233

19. Badia X, Arribas F, Ormaetxe JM, Peinado R, de Los Terreros MS (2007) Development of a questionnaire to measure health-related quality of life $(\mathrm{HRQoL}$ ) in patients with atrial fibrillation (AFQoL). Health Qual Life Outcomes 5:37

20. Arribas F, Ormaetxe JM, Peinado R, Perulero $N$ Ramirez P, Badia X (2010) Validation of the AFQoL, a disease-specific quality of life questionnaire for patients with atrial fibrillation. Europace 12(3):364-370

21. Bonnemeier H, Bosch RF, Kohlhaussen A, Rosin L, Willich SN, Pittrow D et al (2011) Presentation of atrial fibrillation and its management by cardiologists in the ambulatory and hospital setting: MOVE cross-sectional study. Curr Med Res Opin 27(5):995-1003

22. Meinertz T, Kirch W, Rosin L, Pittrow D, Willich SN, Kirchhof $P$ (2011) Management of atrial fibrillation by primary care physicians in Germany: baseline results of the ATRIUM registry. Clin Res Cardiol 100(10):897-905

23. Hohnloser SH, Crijns HJGM, van Eickels M, Gaudin C, Page RL, Torp-Pedersen C et al (2009) Effect of dronedarone on cardiovascular events in atrial fibrillation. N Engl J Med 360(7):668-678

24. Pedersen SS, Kupper N (2010) Representing the patient perspective in the treatment of atrial fibrillation. Europace 12(3):305-306 


\section{Original Contribution}

25. Roalfe AK, Bryant TL, Davies MH, Hackett TG, Saba S, Fletcher K et al (2012) A cross-sectional study of quality of life in an elderly population ( 75 years and over) with atrial fibrillation: secondary analysis of data from the Birmingham Atrial Fibrillation Treatment of the Aged study. Europace 14(10):1420-1427

26. EuroQol Group (1990) EuroQol—a new facility for the measurement of health-related quality of life. Health Policy 16:199-208

27. Bosch RF, Pittrow D, Beltzer A, Kruck I, Kirch W, Kohlhaussen A et al (2013) Gender differences in patients with atrial fibrillation. Herzschrittmacherther Elektrophysiol 24(3):176-183

28. Wynn GJ, Todd DM, Webber M, Bonnett L, McShane J, Kirchhof $P$ et al (2014) The European Heart Rhythm Association symptom classification for atrial fibrillation: validation and improvement through a simple modification. Europace 16(7):965-972

29. Delgado-Rodriguez M, Llorca J (2004) Bias. J Epidemiol Community Health 58(8):635-641 